О. М. Масюк

Дніпровський начіональний університет імені Олеся Гончара

\title{
ДИНАМІКА ФОРМУВАННЯ ТРАВОСТОЮ В НАСАДЖЕННЯХ ОБЛІПИХИ КРУШИНОПОДІБНОЇ НА РІЗНОЯКІСНИХ ВАРІАНТАХ РЕКУЛЬТИВАЦІЇ ПОРУШЕНИХ ЗЕМЕЛЬ ЗАХІДНОГО ДОНБАСУ
}

Проведено біоекоморфічний аналіз флори, який виявив особливості формування травостою за 30-річний період у насадженнях обліпихи крушиноподібної на різних стадіях її розвитку, культивованої в різних типах лісорослинних умов, створених штучними грунтами при рекультивації фітотоксичних відвалів.

Ключові слова: рекультивація порушених земель, травостій, біоекоморфічний аналіз, обліпиха.

\section{А. Н. Масюк}

Днепровский национальный университет имени Олеся Гончара

\section{ДИНАМИКА ФОРМИРОВАНИЯ ТРАВОСТОЯ В НАСАЖДЕНИЯХ ОБЛЕПИХИ КРУШИНОВИДНОЙ НА РАЗНОКАЧЕСТВЕННЫХ ВАРИАНТАХ РЕКУЛЬТИВАЦИИ НАРУШЕННЫХ ЗЕМЕЛЬ ЗАПАДНОГО ДОНБАССА}

Проведен биоэкоморфичный анализ флоры, который выявил особенности формирования травостоя за 30 летний период в насаждениях облепихи крушиновидной на разных стадиях ее развития, культивируемой в разных типах лесорастительных условий, созданных искусственными грунтами при рекультивации фитотоксичных отвалов.

Ключевые слова: рекультивация нарушенных земель, травостой, биоэкоморфический анализ, облепиха.

\author{
O. M. Masiuk \\ Oles Honchar Dnipro National University
}

\section{DYNAMICS OF FORMATION OF GRAS STAND IN PLANTATION OF COMMON SEA BUCKTHORN ON RECLAMATIONS OF DISTURBED LANDS OF DIFFERENT QUALITIES IN THE WESTERN DONBASS}

The goal of our research is studying of the ecomorphic state of grass cover in the reclaimed areas of the Western Donbas. The following tasks were set to achieve the goal: 1) the study of species composition and bioecological analysis of the flora in test areas; 2) determination of the special aspects of the formation of grass stand, depending on the dominant hardy-shrub species along with ecological and edaphic conditions of the studied territory; 3 ) analysis of the dynamics of growth and development of plantations of common sea buckthorn and grass stand under them on technosol with different width and stratigraphy of the made ground.

The object of research is the flora of the phytotoxic refuse tips of the "Blagodatnaya" coalmine, where, a reclamation layer was created by filling brought substrates on the surface of the refuse tips. Those substrates are sand clay, clay loam, red brown clay, humus soil in various combinations (Dnipropetrovsk region, Pavlogradsky area).

The research was carried out in the plantations of common sea buckthorn (Hippophae rhamnoides $L$.) in the age of 10, 14, 23 and 30 years, cultivated in four forms of technosol in the middle and lower parts of the reclaimed refuse tips. Option 1: edaphotope is a rich $25 \mathrm{~cm}$ soil layer of typical chernozem, lower is $55 \mathrm{~cm}$ of old alluvial sand clay, and deeper is mine solid; option 2: edaphotope is represented by an $80 \mathrm{~cm}$ layer of sand clay on a mine

(C) О. М. Масюк, 2017 
solid; option 3: $30 \mathrm{~cm}$ layer of sand clay on a mine solid; option 4: edaphotope is represented by a $140 \mathrm{~cm}$ layer of sand clay on a mine solid.

The research determines that the formation of grass stand on technosol is influenced by the following bioecological features of the sea buckthorn plantations, in which it is formed: the age of the forest stand, the stage of its development, as well as the edaphic conditions, based on stratigraphy and the width of artificial substrates, and the multiyear flood regime of the Samara river

Long-roriferous polycarpic herbs dominate in the spectrum of life forms. The longterm development of the role of the arid element indicates the formation of a structure close to the zonal flora.

The analysis of flora cenotypes showed the leading role of the ruderant complex, which can be explained by the influence of anthropogenic factors (fires) leading to the growth of weeds, which is first stage of restoration. Participation in the formation of flora of meadow, steppe and psamophytic cenotypes indicates the different types of forest growth conditions created by artificial soils.

The adaptation of plants to the nutrient status and moisturization of the substrate, to the light regime, changes in the ratio of different groups is caused by the width of the reclamation layer, which regulates the edaphic volume and the use of the upper layers of technosol. In the plantations of the common sea buckthorn, the best growth and development indicators were recorded in the variant with a maximum layer of sand clay. The number of species in this variant was greater than in chernozem.

Thus, we recommend the width of sand clay from 80 to $140 \mathrm{~cm}$ for the cultivation of the common sea buckthorn.

Keywords: reclamation of disturbed lands, grass stand, biological ecomorphic analysis, common sea buckthorn.

Фітомеліорація - це напрям прикладної екології, який полягає у дослідженні та використанні рослинних систем для покращення характеристик довкілля [12]. Залежно від стану фітоценозів можна зробити висновок про стан грунтового покриву та екосистеми в цілому [3]. Фітомеліоративне закріплення поверхні відвалів шляхом створення деревно-чагарникової і трав'янистої рослинності є завершальним етапом рекультиваційних робіт, внаслідок яких знижується до мінімуму, а в ході розвитку рослинного покриву повністю ліквідується шкідливий вплив промислових відвалів на довкілля [4]. Саме через велике значення стану фітоценозів на деструктивних територіях повинні створюватися такі грунтово-екологічні умови, які б відповідали біологічним особливостям та екологічним потребам рослин, з урахуванням зоо- та мікробоценозних компонентів у зв'язку з їх цільовим призначенням [7]. Дослідними базовими пунктами для проведення науководослідних і експериментальних робіт по лісовій рекультивації та фітомеліорації $\epsilon$, як правило, біогеоценотичні станції і стаціонари. Довготривалі наукові стаціонари включають як еталонні, так і техногенні ландшафти, де експериментальні роботи спрямовані на запобігання тим деструктивним процесам, які призводять до часткової або повної загибелі компонентів біогеоценозів.

На шахтних відвалах Західного Донбасу експедицією ДНУ з 1975 року проводяться комплексні біогеоценотичні дослідження. У результаті узагальнення даних багаторічного експерименту розроблено екологічні прийоми формування стійких і довговічних лісових біогеоценозів в умовах техногенного ландшафту.

Мета проведених нами досліджень: вивчення екоморфічного стану трав'яного покриву на рекультивованих ділянках Західного Донбасу.

Для досягнення мети були поставлені такі задачі:

1. Дослідження видового складу та проведення біоекологічного аналізу флори пробних площ.

2. Визначення особливостей формування травостою залежно від домінуючих деревно-чагарникових порід та еколого-едафічних умов досліджуваної території. 
3. Аналіз динаміки росту та розвитку насаджень обліпихи крушиноподібної та травостою під ними на техноземах з різною потужністю та стратиграфією насипного шару.

Об'єкт та методи досліджень. Об'єкт досліджень - флора фітотоксичних відвалів кам'яновугільної шахти «Благодатна», де для створення рекультиваційного шару застосовувалася насипка на поверхні шахтних відвалів із привезених субстратів, представлених супісками, суглинками, червоно-бурими глинами, гумусованими грунтами в різноманітному сполученні (Дніпропетровська обл., Павлоградський р-н). Териконник шахти «Благодатна» був відсипаний в 1971-1975 роках і в кінцевому результаті представляє собою відвал, складений знизу „пустою" шахтною породою, на поверхні якої були штучно створені одно-, двох- та триярусні структури рекультивованих земель загальною площею 11,4 га та загальним схилом у сторону р. Самари 6-8 південно-західної експозиції.

Дослідження проводилися в насадженнях обліпихи крушиноподібної (Нippophae rhamnoides L.) в 10-, 14-, 23- и 30-річному віці, культивованої на чотирьох варіантах техноземів у средній та нижній частинах рекультивованого відвалу. Варіант 1 - едафотоп представлений родючим грунтовим шаром чорнозему звичайного - 25 см, нижче - давньоалювіальний супісок $(\mathrm{CП})-55$ см, глибше - шахтна порода (ШП); варіант 2 - едафотоп представлений 80-см шаром супіску, нанесеного на шахтну породу; варіант 3 - 30-см шар супіску, нанесеного на шахтну породу; варіант 4 - едафотоп, представлений 140-см шаром супіску, нанесеного на шахтну породу.

У процесі досліджень використано геоботанічні методи досліджень: стаціонарний, описовий, метод пробних площ, проведено біоекоморфічний аналіз [1; $10 ; 11 ; 13]$. Видовий склад визначався за «Определителем высших растений Украины» [9].

Результати та їх обговорення. Характеристика 10 річних насаджень обліпихи крушиноподібної.

Bapiaнm 1. На першому варіанті насадження обліпихи крушиноподібної досягли середньої висоти - 3,86 м та діаметра - 3,67 см. На одному га зареєстровано 2285 дерев. Тип екологічної структури - напівосвітлений, друга вікова стадія розвитку (жердняк). Зімкнутість крон - 0,9.

Травостій представлено 11 видами рослин, серед яких зустрічаються багаторічники (37\%), однорічники (36 \%) та дворічники $(27 \%)$. У класифікації за Раункієром присутні гемікриптофіти (37\%), терофіти (36 \%) та геофіти (27 \%). По відношенню до багатства грунту на цій ділянці зустрічають лише мезотрофи (100\%). За гігроморфами присутні мезоксерофіти (58\%) та ксеромезофіти (42\%). Щодо забезпеченості світлом домінують геліофіти (90 \%), є представники сціогеліофітів (10\%). Екологічний аналіз показує, що у травостої зустрічаються рудеранти (44\%), степанти (31\%) та пратанти (25\%).

Bapiaнm 2. Середня висота дерев на варіанті становить 4,82 м та діаметр 4,7 см. Отже, на супіску в 10-річному віці лінійні показники росту дещо вищі, ніж на чорноземі, за рахунок більшої потужності штучного грунту. На одному га зареєстровано 2800 дерев. Тип екологічної структури - напівосвітлений, друга вікова стадія розвитку. Зімкнутість крон -1 .

Травостій представлений 5 видами рослин, серед яких зустрічаються багаторічники (60\%) та дворічники (40 \%). Тут флора дещо бідніша, ніж на першому варіанті, за рахунок більшої зімкненості деревостану. За Раункієром зустрічаються гемікриптофіти (60 \%) та геофіти (40 \%). За трофоморфами домінують мезотрофи (100\%). По відношенню до вологості грунту зустрічаються ксеромезофіти (60 \%) та мезоксерофіти (40 \%). У класифікації за геліоморфами переважають геліофіти (80 \%), що можна пояснити ажурністю крон обліпихи; зустрічаються сціогеліофіти $(20$ \%). У класифікації за ценоморфами зустрічаються рудеранти (40\%), сте- 
панти (40 \%) та пратанти (20 \%). Таким чином, у 10-річних насадженнях обліпихи крушиноподібної було таке кількісне співвідношення біоморф та екоморф між різними варіантами грунтів (табл. 1).

Таблиия 1

\section{Порівняльна характеристика травостою, що формується в 10-річних насадженнях обліпихи крушиноподібної}

\begin{tabular}{|c|c|c|c|c|}
\hline \multicolumn{3}{|c|}{ Варіант досліду } & 1 & 2 \\
\hline \multirow{6}{*}{ Біоморфи } & \multirow{3}{*}{ за Раункієром } & $\mathrm{HKr}, \%$ & 37 & 60 \\
\hline & & $\mathrm{T}, \%$ & 36 & 0 \\
\hline & & $\mathrm{G}, \%$ & 27 & 40 \\
\hline & \multirow{3}{*}{ життєва форма } & Од, \% & 36 & 0 \\
\hline & & Дв, \% & 27 & 40 \\
\hline & & Бр, \% & 37 & 60 \\
\hline \multirow{8}{*}{ Екоморфи } & \multirow{3}{*}{ ценоморфи } & $\mathrm{Ru}, \%$ & 44 & 40 \\
\hline & & St, $\%$ & 31 & 40 \\
\hline & & $\operatorname{Pr}, \%$ & 25 & 20 \\
\hline & \multirow{2}{*}{ гігроморфи } & MsKs, $\%$ & 58 & 40 \\
\hline & & KsMs, \% & 42 & 60 \\
\hline & трофоморфи & MsTr, \% & 100 & 100 \\
\hline & \multirow{2}{*}{ геліоморфи } & $\mathrm{He}, \%$ & 90 & 80 \\
\hline & & $\mathrm{ScHe}, \%$ & 10 & 20 \\
\hline
\end{tabular}

Примітка: $\mathrm{HKr}$ - гемікриптофіти, T - терофіти, G - геофіти, Од. - однорічники, Дв дворічники, Бр - багаторічники, $\mathrm{Ru}$ - рудеранти, $\mathrm{St}$ - степанти, $\mathrm{Pr}$ - пратанти, MsKs - мезоксерофіти, KsMs - ксеромезофіти, MsTr - мезотрофи, Не - геліофіти, $\mathrm{ScHe}$ - сціогеліофіти.

У насадженнях дерева краще розвивались на супіщаному едафотопі, ніж на варіанті з шаром чорнозему звичайного. У травостої 2-го варіанта через погіршення грунтових умов і високу зімкненість деревостану зменшується кількість видів, але майже не змінюється співвідношення всередині груп. На супіщаному варіанті слід зазначити відсутність терофітів та однорічників. Також зменшується кількість мезоксерофітів, що вказує на більш посушливі умови.

Характеристика 14-річних насаджень обліпихи крушиноподібної.

Bapiaнm 1. Дослідження показали, що насадження обліпихи крушиноподібної досягли середньої висоти -5 м та діаметра - 7,1 см. На одному га зареєстровано 1524 дерев. Тип екологічної структури - напівосвітлений, друга вікова стадия розвитку. Зімкнутість крон - 0,9.

Травостій представлено 12 видами рослин, серед них зустрічаються багаторічники (67\%), дворічники (22\%) та однорічники (11\%). У класифікації за Раункієром превалюють гемікриптофіти (89 \%) та терофіти (11\%). По відношенню до багатства грунту переважають мезотрофи (45 \%) та мегатрофи (45\%), зустрічаються оліготрофи (10\%). За гігроморфами найбільше ксеромезофітів (67 \%), мезоксерофітів $22 \%$ та мезофітів $11 \%$. Залежно від відношення до сонячного світла зустрічаються сціогеліофіти (56 \%) та геліофіти (44\%). Екологічний аналіз показав, що в рослинності зустрічаються пратанти (40\%), рудеранти $(27 \%)$, степанти $(20 \%)$ та сильванти (13\%). Поява сільвантів у 14-річному віці свідчить про зростання середовищетвірної ролі лісових культур.

Bapiarm 2. Насадження обліпихи крушиноподібної досягли середньої висоти $-4,81$ м та діаметра $-7,83$ см. На одному га зареєстровано 1559 дерев. Тип екологічної структури - напівосвітлений, друга вікова стадія розвитку. Зімкнутість крон $-0,9$. 
Травостій представлено 10 видами рослин, серед них зустрічаються багаторічники (67 \%) та дворічники (33 \%). За Раункієром переважають гемікриптофіти (78 \%) та геофіти (22\%). У класифікації за трофоморфами зустрічаються мегатрофи (56 \%), мезотрофи (33\%) та оліготрофи (11\%). По відношенню до вологості грунту присутні ксеромезофіти (89 \%) та мезофіти (11\%). По відношенню до забезпеченості світлом зустрічаються сціогеліофіти (67 \%) та геліофіти (33\%). Екологічний аналіз показав, що в рослинності зустрічаються рудеранти (33\%), пратанти (33\%), степанти (17\%) та сильванти (17\%).

Bapiaнm 3. Насадження обліпихи крушиноподібної на цьому варіанті досягли середньої висоти - 3,1 м та діаметра - 3,5 см. Порівняно з варіантом 1 (чорнозем) тут при незначному зростанні потужності рекультиваційного шару лінійні показники росту менші, бо тут менш родючий супісок. На одному га зареєстровано 1335 дерев. Тип екологічної структури - напівосвітлений, співпадає 3 другою віковою стадією розвитку. Зімкнутість крон - 0,9.

Травостій представлено 13 видами рослин, серед них зустрічаються багаторічники (70 \%), однорічники (20\%) та дворічники (10\%). У класифікації за Раункієром превалюють гемікриптофіти (55\%), геофіти (27\%) та терофіти (18 \%). По відношенню до багатства грунтів зустрічаються мезотрофи (38 \%), мегатрофи (38 \%) та оліготрофи (23 \%); отже, біоіндикаторні показники засвідчують меншу родючість едафотопу порівняно з першим варіантом. У класифікації за гігроморфами найбільше ксеромезофітів (80 \%), ксерофітів (10\%) та мезофітів (10\%). За геліоморфами зустрічаються геліофіти (60\%) та сціогеліофіти (40\%). За ценоморфами домінують пратанти (36\%), степанти (27\%), рудеранти (18 \%), зустрічаються сильванти (9 \%), псамофіти (5\%) та полютанти (5 \%). Поява полютантів пояснюється неглибоким (30 см) заляганням водопідпірного горизонту шахтної породи.

Bapiaнm 4. Насадження обліпихи крушиноподібної на цьому варіанті досягли середньої висоти - 7 м та діаметра - 7,2 см. На одному га зареєстровано 1200 дерев. Тип екологічної структури - напівосвітлений, співпадає 3 другою віковою ступінню розвитку (жердняк). Зімкнутість крон - 1 .

Травостій представлено 18 видами рослин, серед них зустрічаються багаторічники (56 \%), дворічники (31 \%) та однорічники (13\%). Серед біоморф за Раункієром переважають гемікриптофіти (69 \%), рідше зустрічаються геофіти (19\%) та терофіти (13\%). У класифікації за вимогливістю до багатства грунту зустрічаються мегатрофи (45\%), мезотрофи (35\%) та оліготрофи (20\%). За гігроморфами домінують ксеромезофіти (67 \%), мезоксерофіти займають $27 \%$ та мезофіти 7 \%. Порівняння за складом гігроморф з варіантом 2 , де також супісок, але значно меншої потужності (80 см), показує біоіндикацію біднішого зволоження, що можна пояснити водозатримуючим впливом шахтної породи, більш відчутним для кореневих систем на малопотужних грунтах.

За геліоморфами переважають сціогеліофіти (63\%) та геліофіти (37\%). У класифікації за ценоморфами найчастіше зустрічаються рудеранти (41\%), пратанти $(28 \%)$, степанти (17\%) та сильванти (10\%).

Таким чином, у 14-річних насадженнях обліпихи крушиноподібної було таке кількісне співвідношення біоморф та екоморф між різними варіантами грунтів (табл. 2).

Для деревних насаджень обліпихи крушиноподібної грунтовий насип у 30 см $\epsilon$ недостатнім для нормального росту та розвитку, однак тільки на цьому варіанті з'являються представники псамофітів та полютантів, як найбільш пристосованих для таких жорстких умов зростання. Найбільша кількість видів спостерігається на варіанті з насипом супіску у 140 см, що є навіть кращим варіантом для розвитку травостою, ніж 20 см насип грунтової маси чорнозему звичайного. Від чорноземного до супіщаного варіантів зменшується кількість гемікриптофітів, пратантів та геліофітів. Майже не змінюється гідрологічний режим, лише 2 та 3 варі- 
анти характеризуються відсутністю мезоксерофітних видів. Від варіанта із мінімальним шаром супіску до варіанта із максимальним шаром супіску зростає кількість видів - оліготрофів.

Таблиия 2

Порівняльна характеристика травостою, що формусться в 14-ти річних насадженнях обліпихи крушиноподібної

\begin{tabular}{|c|c|c|c|c|c|c|}
\hline \multicolumn{3}{|c|}{ Варіант досліду } & 1 & 2 & 3 & 4 \\
\hline \multirow{6}{*}{ Біоморфи } & \multirow{3}{*}{ за Раункієром } & $\mathrm{HKr}, \%$ & 89 & 78 & 55 & 69 \\
\hline & & $\mathrm{T}, \%$ & 11 & 0 & 18 & 19 \\
\hline & & $\mathrm{G}, \%$ & 0 & 22 & 27 & 13 \\
\hline & \multirow{3}{*}{ життєва форма } & Од, \% & 11 & 0 & 20 & 13 \\
\hline & & Дв, \% & 22 & 33 & 10 & 31 \\
\hline & & Бр, \% & 67 & 67 & 70 & 56 \\
\hline \multirow{16}{*}{ Екоморфи } & \multirow{7}{*}{ ценоморфи } & $\mathrm{Ru}, \%$ & 27 & 33 & 18 & 41 \\
\hline & & Sil, \% & 13 & 17 & 9 & 10 \\
\hline & & St, $\%$ & 20 & 17 & 27 & 17 \\
\hline & & Hal, \% & 0 & 0 & 0 & 3 \\
\hline & & Pr, $\%$ & 40 & 33 & 36 & 28 \\
\hline & & Ps, $\%$ & 0 & 0 & 5 & 0 \\
\hline & & Pal, \% & 0 & 0 & 5 & 0 \\
\hline & \multirow{4}{*}{ гігроморфи } & MsKs, $\%$ & 22 & 0 & 0 & 27 \\
\hline & & $\mathrm{Ks}, \%$ & 0 & 0 & 10 & 0 \\
\hline & & $\mathrm{Ms}, \%$ & 11 & 11 & 10 & 7 \\
\hline & & KsMs, $\%$ & 67 & 89 & 80 & 67 \\
\hline & \multirow{3}{*}{ трофоморфи } & $\operatorname{MgTr}, \%$ & 45 & 56 & 38 & 45 \\
\hline & & MsTr, \% & 45 & 33 & 38 & 35 \\
\hline & & OgTr, \% & 9 & 11 & 23 & 20 \\
\hline & \multirow{2}{*}{ геліоморфи } & $\mathrm{He}, \%$ & 44 & 33 & 60 & 38 \\
\hline & & $\mathrm{ScHe}, \%$ & 56 & 67 & 40 & 63 \\
\hline
\end{tabular}

Примітка: Sil - сильванти, Hal - галофіти, Ps - псамофіти, Pal - гелофіти, Ks - ксерофіти, Ms - мезофіти, $\mathrm{Mg} \operatorname{Tr}$ - мегатрофи, $\operatorname{Og} \operatorname{Tr}$ - оліготрофи.

Характеристика 23-річних насаджень обліпихи крушиноподібної.

Bapiaнm 1. В насадженнях середня висота дерев становить 4,9 м та діаметр 8,5 см. Незначні щорічні прирости лінійних показників свідчать про недостатню потужність насипного шару. На одному га зареєстровано 1524 дерева. Тип екологічної структури - напівосвітлений, вікова стадія розвитку - друга. Зімкнутість крон - 0,9.

Травостій представлено 11 видами рослин, серед них зустрічаються багаторічники (84 \%), однорічники (7 \%) та дворічники (7 \%). Серед біоморф за Раункієром переважають гемікриптофіти (57\%) та геофіти (43\%). Серед трофоморф основну масу видів складають мегатрофи (60 \%) та мезотрофи (40 \%). По відношенню до водного режиму переважають ксеромезофіти (43\%) та мезоксерофіти (42 \%), зустрічаються ксерофіти (15\%). У класифікації за геліоморфами зустрічаються сціогеліофіти (55\%) та геліофіти (45 \%). Екологічний аналіз показав, що в рослинному покриві переважають рудеранти (57 \%), пратанти (29\%) та степанти (14 \%).

Bapiaнm 2. Середня висота дерев - 5,6 м та діаметр - 9,1 см. На одному га зареєстровано 1070 дерев. Тип екологічної структури - напівосвітлений, вікова стадія розвитку - перехідна, від другої (жердняк) до третьої (зрідження). Зімкнутість крон - 0,7. 
Травостій представлено 11 видами рослин, серед них зустрічаються багаторічники (67 \%) та дворічники (33 \%). Серед біоморф за Раункієром у досліджених умовах переважають гемікриптофіти (67\%) та геофіти (33\%). По відношенню до багатства грунтів виявлено мезотрофи (50\%) та мегатрофи (50 \%). За гігроморфами переважають ксеромезофіти (50\%), зустрічаються мезоксерофіти (17\%), мезофіти (17\%) та ксерофіти (16\%). По відношенню до світла домінуючими є сціогеліофіти (65\%) та геліофіти (35\%). Серед ценоморф у травостої переважають рудеранти (50\%), пратанти (33\%) та псамофіти (17\%).

Bapiaнm 3. Насадження обліпихи на цьому варіанті мають середню висоту 3,5 м та діаметр - 4 см. На одному га зареєстровано 1250 дерев. Тип екологічної структури - освітлений, співпадає з третьою віковою стадією розвитку (зрідження). Зімкнутість крон - 0,5.

Травостій представлено 14 видами рослин, серед них зустрічаються багаторічники (75 \%), однорічники та дворічники складають по 12,5\%. У класифікації за Раункієром зустрічаються гемікриптофіти (62 \%) та геофіти (38 \%). За трофоморфами співвідношення видів складає мезотрофів - 75 \% та мегатрофів - $25 \%$. По відношенню до водного режиму найбільше мезоксерофітів (50 \%) та ксеромезофітів (38\%), рідше зустрічаються мезофіти (12\%). За геліоморфами присутні сціогеліофіти (63\%) та геліофіти (37 \%). За ценоморфами переважають рудеранти $(62 \%)$, пратанти зустрічаються у $25 \%$ випадків і псамофіти у $13 \%$.

У зв'язку з тим що на четвертому варіанті була низова пожежа, дані з травостою не визначалися, за його відсутності.

Таким чином, в 23-річних насадженнях обліпихи крушиноподібної було таке кількісне співвідношення біоморф та екоморф між різними варіантами грунтів (табл. 3).

Табличя 3

\section{Порівняльна характеристика травостою, що формусться в 23-річних насадженнях обліпихи крушиновидної}

\begin{tabular}{|c|c|c|c|c|c|}
\hline \multicolumn{3}{|c|}{ Варіант досліду } & 1 & 2 & 3 \\
\hline \multirow{5}{*}{ Біоморфи } & \multirow{2}{*}{ за Раункієром } & $\mathrm{HKr}, \%$ & 57 & 67 & 62 \\
\hline & & $\mathrm{G}, \%$ & 43 & 33 & 38 \\
\hline & \multirow{3}{*}{ життєва форма } & Од, \% & 7 & 0 & 12,5 \\
\hline & & Дв, \% & 7 & 33 & 12,5 \\
\hline & & Бр, \% & 86 & 67 & 75 \\
\hline \multirow{12}{*}{ Екоморфи } & \multirow{4}{*}{ ценоморфи } & $\mathrm{Ru}, \%$ & 57 & 50 & 62 \\
\hline & & St, $\%$ & 14 & 0 & 0 \\
\hline & & $\operatorname{Pr}, \%$ & 29 & 33 & 25 \\
\hline & & Ps, $\%$ & 0 & 17 & 13 \\
\hline & \multirow{4}{*}{ гігроморфи } & MsKs, \% & 42 & 17 & 50 \\
\hline & & $\mathrm{Ks}, \%$ & 15 & 16 & 0 \\
\hline & & Ms, \% & 0 & 17 & 12 \\
\hline & & KsMs, \% & 43 & 50 & 38 \\
\hline & \multirow{2}{*}{ трофоморфи } & $\operatorname{MgTr}, \%$ & 60 & 50 & 25 \\
\hline & & MsTr, \% & 40 & 50 & 75 \\
\hline & \multirow{2}{*}{ геліоморфи } & $\mathrm{He}, \%$ & 45 & 35 & 37 \\
\hline & & $\mathrm{ScHe}, \%$ & 55 & 65 & 63 \\
\hline
\end{tabular}

За результатами досліджень можна зауважити, що ріст та розвиток насаджень обліпихи крушиноподібної залежать від едафічних умов техноземів (ссилки). Головним фактором, що визначає і рівень родючості, і ступінь зволоження, є потужність едафотопу. 3 підвищенням потужності відсипки супіщаних відкладень по- 
кращуються лісорослинні умови, які позитивно впливають на продуктивність деревостану і екоморфічні показники травостою.

У трав'яному покриві основну масу складають багаторічники (67-86 \%). Домінування гемікриптофітів серед клімаморф просліджуються на всіх варіантах $(57-67 \%)$.

Основну масу ценоморф складають бур'яни (50-62 \%) та лучні рослини (25-33 \%). Степові рослини зустрічаються тільки на варіанті з нанесеним шаром чорнозему, а види, характерні для пісків - тільки на супіщаних варіантах.

Формування гігроморф відбувається за рахунок ксеромезофітів та мезоксерофітних видів, залежно від кількості опадів, внутрішнього стоку води та гідрологічного режиму прилеглої заплави річки Самари.

Відношення травостою до наявності поживних речовин у грунті показало найкращу адаптивну здатність у мегатрофів на варінтах 1 і 2, що пов'язано з біологічними особливостями обліпихи, а саме, азотфіксуючою здатністю, властивостями родючого шару та оптимальною потужністю супіщаного едафотопу.

Серед геліоморф на усіх варіантах домінуюче положення займають сціогеліофіти (55-65 \%), а простір, що звільняється за рахунок зрідження, заповнюється геліофітами (35-45\%).

Характеристика 30-річних насаджень обліпихи крушиноподібної.

У 2009 році в насадженнях обліпихи крушиноподібної була пожежа, тому під час досліджень у 2010 році варіанти 2 та 3 характеризувались однаковим видовим складом травостою.

Середня висота дерев досягла 3,2 м, діаметр 12,4 см. На одному га зареєстровано 1000 дерев. Тип екологічної структури - освітлений, вікова ступінь розвитку друга (жердняк). Зімкнутість крон - 0,5.

Травостій представлено 4 видами рослин, серед них зустрічаються багаторічники (75 \%) та дворічники (25\%). По класифікації за Раункієром домінують гемікриптофіти (75\%) та геофіти (25\%). По відношенню до наявності поживних речовин у грунті домінують мезотрофи (80 \%) та оліготрофи (20 \%). По класифікації за гігроморфами превалюють мезоксерофіти (50\%), мезофіти (25\%) та ксерофіти (25\%). За геліоморфами найбільше геліофітів (75 \%), рідше зустрічаються сціогеліофіти (25\%). Екологічний аналіз показав, що в рослинному покриві зустрічаються рудеранти (50 \%), пратанти (25\%) та степанти (25\%).

Таким чином, у 30-річних насадженнях обліпихи крушиноподібної було таке кількісне співвідношення біоморф та екоморф (табл. 4).

\section{Порівняльна характеристика травостою, що формується}

Таблиия 4 в 30-річних насадженнях обліпихи крушиноподібної

\begin{tabular}{|c|c|c|c|c|}
\hline \multicolumn{3}{|c|}{ Варіант досліду } & 2 & 3 \\
\hline \multirow{4}{*}{ Біоморфи } & \multirow{2}{*}{ за Раункієром } & $\mathrm{HKr}, \%$ & 75 & 75 \\
\hline & & $\mathrm{G}, \%$ & 25 & 25 \\
\hline & \multirow{2}{*}{ життєва форма } & Дв, \% & 25 & 25 \\
\hline & & Бр, \% & 75 & 75 \\
\hline \multirow{8}{*}{ Екоморфи } & \multirow{3}{*}{ ценоморфи } & $\mathrm{Ru}, \%$ & 50 & 50 \\
\hline & & St, $\%$ & 25 & 25 \\
\hline & & $\operatorname{Pr}, \%$ & 25 & 25 \\
\hline & \multirow{3}{*}{ гігроморфи } & $\mathrm{Ks}, \%$ & 25 & 25 \\
\hline & & Ms, $\%$ & 25 & 25 \\
\hline & & KsMs, \% & 50 & 50 \\
\hline & \multirow{2}{*}{ трофоморфи } & MsTr, $\%$ & 80 & 80 \\
\hline & & OgTr, $\%$ & 20 & 20 \\
\hline
\end{tabular}


Закінчення табл. 4

\begin{tabular}{|l|c|c|c|c|}
\hline \multicolumn{2}{|c|}{ Варіант досліду } & 2 & 3 \\
\hline \multirow{2}{*}{ геліоморфи } & $\mathrm{He}, \%$ & 75 & 75 \\
\cline { 3 - 4 } & & $\mathrm{ScHe}, \%$ & 25 & 25 \\
\hline
\end{tabular}

Через жорсткі грунтові умови на дослідному варіанті був невеликий видовий склад травостою. Через часткову пожежу змінився тип екологічної структури 3 напівосвітленого на освітлений, майже зникли представники сціогеліофітів. Умови зволоження також змінились на більш посушливі, що спричинило зникнення мезоксерофітних видів.

Динаміка формування травостою в насадженнях обліпихи крушиновидної.

Протягом 30 років з моменту висадки обліпихи крушиновидної змінювались екологічні умови досліджуваної території $[5,6,8]$, а 3 ними змінювався видовий склад травостою та продуктивність деревостану (табл. 5).

Динаміка росту та розвитку обліпихових насаджень

\begin{tabular}{|c|c|c|c|c|c|c|c|}
\hline 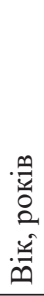 & 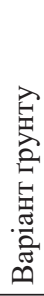 & 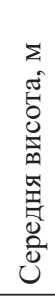 & 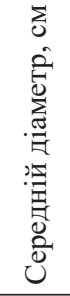 & 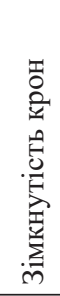 & 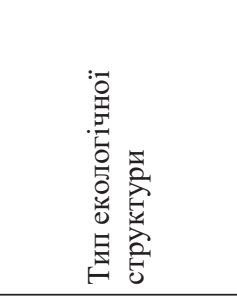 & 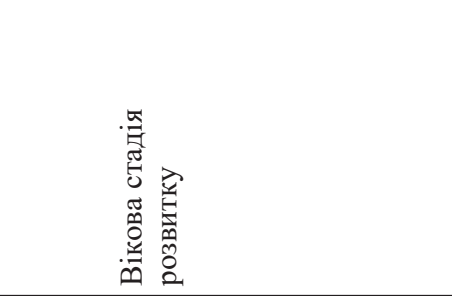 & 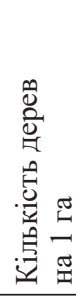 \\
\hline \multirow{2}{*}{10} & 1 & 3,9 & 3,7 & 0,9 & напівосвітлений & друга & 2285 \\
\hline & 2 & 4,8 & 4,7 & 1 & напівосвітлений & друга & 2800 \\
\hline \multirow{4}{*}{14} & 1 & 5,0 & 7,1 & 0,9 & напівосвітлений & друга & 1524 \\
\hline & 2 & 4,8 & 7,8 & 0,9 & напівосвітлений & друга & 1559 \\
\hline & 3 & 3,1 & 3,5 & 0,9 & напівосвітлений & друга & 1335 \\
\hline & 4 & 7,0 & 7,2 & 1 & напівосвітлений & друга & 1200 \\
\hline \multirow{3}{*}{23} & 1 & 4,9 & 8,5 & 0,9 & напівосвітлений & друга & 1524 \\
\hline & 2 & 5,6 & 9,1 & 0,7 & напівосвітлений & $\begin{array}{c}\text { перехідна стадія від жердняка до } \\
\text { зрідження }\end{array}$ & 1070 \\
\hline & 3 & 3,5 & 4,0 & 0,5 & освітлений & третя & 1250 \\
\hline 30 & 2 & 3,2 & 12,4 & 0,5 & освітлений & друга & 1000 \\
\hline
\end{tabular}

Слід зазначити, що найкращі таксаційні показники деревостану були зареєстровані на варіанті з максимальним шаром супіску. На варіанті з мінімальним шаром супіску тип екологічної структури змінився 3 напівосвітленого на освітлений, зімкнутість крон зменшилася 31 до 0,5 та змінилася вікова ступінь розвитку 3 другої (жердняк) на третю (зрідження). На всіх варіантах грунтів у 2 рази зменшилася кількість дерев на га.

Розгядаючи в динаміці формування травостою на чорноземному варіанті, можна виділити чіткі тенденції за такими показниками (табл. 6). 3 віком відбувається збільшення багаторічних видів трав з 36 до 86 \% за рахунок зменшення одно- і дворічних відповідно з 36 до 7 \% та з 27 до 7 \%.

Якщо на ранніх стадіях розвитку деревостану в ньому на $100 \%$ знаходилися мезотрофні види, то по мірі старіння його відбувається тенденція зміни травостою на мегатрофні, які до 23 років досягають 60 \%. Це можна пояснити поступовим збагаченням грунту - як за рахунок азотфіксуючої здатності обліпихи, так і завдяки мінералізації рослинного опаду. 
До 10-річного віку спостерігалося домінування геліофітів (90 \%). У подальші роки йшла тенденція по їх зменшенню та стабілізації на рівні 44-45 \% за рахунок збільшення сціогеліофітів, які з 10 \% збільшили свою присутність до 55-56 \%.

Серед клімаморф зустічаються гемікриптофіти, геофіти та терофіти, співвідношення яких змінюється в різний віковий період. Основну масу ценоморф складають бур'яни та лучні види. Відсоток степових рослин з роками зменшується.

Слід зазначити, що більше адаптованими до водного режиму даних лісорослиних умов $\epsilon$ мезоксерофітні та ксеромезофітні рослини. Але залежно від гідрологічних умов (посуха, паводок ріки Самари) можуть з'являтися ксерофітні, або мезофітні види.

Таблиия 6

Динаміка формування травостою в насадженнях обліпихи крушиноподібної на першому варіанті з використанням грунтової маси чорнозему звичайного

\begin{tabular}{|c|c|c|c|c|c|}
\hline \multicolumn{3}{|c|}{ Вік насаджень } & 10 років & 14 років & 23 років \\
\hline \multirow{6}{*}{ Біоморфи } & \multirow{3}{*}{ за Раункієром } & $\mathrm{HKr}, \%$ & 36 & 89 & 57 \\
\hline & & $\mathrm{T}, \%$ & 36 & 11 & 0 \\
\hline & & $\mathrm{G}, \%$ & 27 & 0 & 43 \\
\hline & \multirow{3}{*}{ життєва форма } & Од, \% & 36 & 11 & 7 \\
\hline & & Дв, \% & 27 & 22 & 7 \\
\hline & & Бр, \% & 36 & 67 & 86 \\
\hline \multirow{13}{*}{ Екоморфи } & \multirow{4}{*}{ ценоморфи } & $\mathrm{Ru}, \%$ & 44 & 27 & 57 \\
\hline & & Sil, \% & 0 & 13 & 0 \\
\hline & & St, $\%$ & 31 & 20 & 14 \\
\hline & & $\operatorname{Pr}, \%$ & 25 & 40 & 29 \\
\hline & \multirow{4}{*}{ гігроморфи } & MsKs, $\%$ & 58 & 22 & 42 \\
\hline & & $\mathrm{Ms}, \%$ & 0 & 11 & 0 \\
\hline & & $\mathrm{Ks}, \%$ & 0 & 0 & 15 \\
\hline & & KsMs, $\%$ & 42 & 67 & 43 \\
\hline & \multirow{3}{*}{ трофоморфи } & $\operatorname{MgTr}, \%$ & 0 & 45 & 60 \\
\hline & & MsTr, $\%$ & 100 & 45 & 40 \\
\hline & & OgTr, \% & 0 & 9 & 0 \\
\hline & \multirow{2}{*}{ геліоморфи } & $\mathrm{He}, \%$ & 90 & 44 & 45 \\
\hline & & $\mathrm{ScHe}, \%$ & 10 & 56 & 55 \\
\hline
\end{tabular}

Характерною особливістю травостою на другому варіанті (табл. 7) є відсутність однорічників серед життєвих форм, поступове зростання відсотка багаторічних видів з 60 до 75 \%, домінування гемікриптофітів над геофітами. Переважна більшість рудерантів, постійна присутність пратантів та частково степантів, в окремі роки з'являються псамофіти; перевага ксеромезофітів, яким складають конкуренцію залежно від виду та гідрологічних умов мезоксерофіти, ксерофіти та мезофіти. Серед трофоморф постійну участь у травостої беруть мезотрофи, які можуть доповнюватися мега- та оліготрофними видами. На початкових стадіях формування обліпихи панують геліофіти, які змінюються сціогеліофітами в період найбільшого розвитку деревостану та які повертаються у процесі зрідження на домінуючі позиції.

Таблиия 7

Динаміка розвитку флори травостою в насадженнях обліпихи крушиноподібної на варіанті з використанням шару супіску товщиною 80 см

\begin{tabular}{|c|c|c|c|c|c|c|}
\hline \multicolumn{2}{|c|}{ Вік насаджень } & 10 років & 14 років & 23 років & 30 років \\
\hline \multirow{2}{*}{ Біоморфи } & \multirow{2}{*}{ за Раункієром } & $\mathrm{HKr}, \%$ & 60 & 78 & 67 & 75 \\
\cline { 3 - 7 } & $\mathrm{G}, \%$ & 40 & 22 & 33 & 25 \\
\hline
\end{tabular}


Закінчення табл. 7

\begin{tabular}{|c|c|c|c|c|c|c|}
\hline \multicolumn{3}{|c|}{ Вік насаджень } & 10 років & 14 років & 23 років & 30 років \\
\hline & \multirow{3}{*}{ життєва форма } & Од, \% & 0 & 0 & 0 & 0 \\
\hline & & Дв, \% & 40 & 33 & 33 & 25 \\
\hline & & Бр, \% & 60 & 67 & 67 & 75 \\
\hline \multirow{14}{*}{ Екоморфи } & \multirow{5}{*}{ ценоморфи } & $\mathrm{Ru}, \%$ & 40 & 33 & 50 & 50 \\
\hline & & Sil, \% & 0 & 17 & 0 & 0 \\
\hline & & St, $\%$ & 40 & 17 & 0 & 25 \\
\hline & & Ps, $\%$ & 0 & 0 & 17 & 0 \\
\hline & & $\operatorname{Pr}, \%$ & 20 & 33 & 33 & 25 \\
\hline & \multirow{4}{*}{ гігроморфи } & MsKs, \% & 40 & 0 & 17 & 0 \\
\hline & & $\mathrm{Ks}, \%$ & 0 & 0 & 16 & 25 \\
\hline & & Ms, \% & 0 & 11 & 17 & 25 \\
\hline & & KsMs, \% & 60 & 89 & 50 & 50 \\
\hline & \multirow{3}{*}{ трофоморфи } & $\operatorname{MgTr}, \%$ & 0 & 56 & 50 & 0 \\
\hline & & MsTr, $\%$ & 100 & 33 & 50 & 80 \\
\hline & & OgTr, $\%$ & 0 & 11 & 0 & 20 \\
\hline & \multirow{2}{*}{ геліоморфи } & $\mathrm{He}, \%$ & 80 & 33 & 35 & 75 \\
\hline & & $\mathrm{ScHe}, \%$ & 20 & 67 & 65 & 25 \\
\hline
\end{tabular}

На варіанті з мінімальним відсипаним шаром супіску (табл. 8) спостерігається тенденція до збільшення дворічних видів, збільшення та стабілізації багаторічних, та зменшення і зникнення однорічних рослин. Серед біоморф (за Раункієром) зустрічаються гемікриптофіти (домінування) та геофіти; терофіти тільки на ранніх стадіях розвитку деревостану.

3 ценоморф постійно присутні рудеранти та пратанти. Залежно від віку та гідрологічних умов у наявності можуть бути степанти, псамофіти і навіть гелофіти та сильванти.

В адаптації рослин до живлення проглядається чітка тенденція скорочення видів мегатрофної групи до їх зникнення, і зворотна реакція мезотроф - поступове збільшення їх до повного домінування в 30-річному віці насадження.

Гігроморфи повністю відображають гідрологічний режим, який складається в даних техноземах у певний період часу та окремі роки і пов'язаний з кліматичними умовами та наявністю або відсутністю повеней річки Самари.

Табличя 8

Динаміка розвитку флори травостою

в насадженнях обліпихи крушиноподібної

на варіанті з використанням шару супіску товщиною 30 см

\begin{tabular}{|c|c|c|c|c|c|}
\hline \multicolumn{3}{|c|}{ Вік насадження } & 14 років & 23 років & 30 років \\
\hline \multirow{6}{*}{ Біоморфи } & \multirow{3}{*}{ за Раункієром } & $\mathrm{HKr}, \%$ & 55 & 62 & 75 \\
\hline & & $\mathrm{T}, \%$ & 18 & 0 & 0 \\
\hline & & $\mathrm{G}, \%$ & 27 & 38 & 25 \\
\hline & \multirow{3}{*}{ життєва форма } & Од, \% & 20 & 12,5 & 0 \\
\hline & & Дв, \% & 10 & 12,5 & 25 \\
\hline & & Бр, \% & 70 & 75 & 75 \\
\hline \multirow{6}{*}{ Екоморфи } & \multirow{6}{*}{ ценоморфи } & $\mathrm{Ru}, \%$ & 18 & 62 & 50 \\
\hline & & Sil, \% & 9 & 0 & 0 \\
\hline & & St, $\%$ & 27 & 0 & 25 \\
\hline & & $\operatorname{Pr}, \%$ & 36 & 25 & 25 \\
\hline & & Ps, $\%$ & 5 & 13 & 0 \\
\hline & & $\mathrm{Pal}, \%$ & 5 & 0 & 0 \\
\hline
\end{tabular}


Закінчення табл. 8

\begin{tabular}{|c|c|c|c|c|}
\hline \multicolumn{2}{|c|}{ Вік насадження } & 14 років & 23 років & 30 років \\
\hline \multirow{4}{*}{ гігроморфи } & MsKs, \% & 0 & 50 & 0 \\
\hline & $\mathrm{Ks}, \%$ & 10 & 0 & 25 \\
\hline & Ms, $\%$ & 10 & 12 & 25 \\
\hline & KsMs, \% & 80 & 38 & 50 \\
\hline \multirow{3}{*}{ трофоморфи } & $\operatorname{MgTr}, \%$ & 38 & 25 & 0 \\
\hline & MsTr, $\%$ & 38 & 75 & 80 \\
\hline & $\operatorname{Og} \operatorname{Tr}, \%$ & 23 & 0 & 20 \\
\hline \multirow{2}{*}{ геліоморфи } & $\mathrm{He}, \%$ & 60 & 37 & 75 \\
\hline & $\mathrm{ScHe}, \%$ & 40 & 63 & 25 \\
\hline
\end{tabular}

Слід вказати на конкуренцію між сціогеліофітами та геліофітами; домінування та свіввідношення між ними залежить від зімкнення крон у різних стадіях розвитку деревостану.

\section{Висновки.}

1. На розвиток трав'яного покриву на техноземах впливають біоекологічні особливості обліпихових насаджень, в яких він формується: вік деревостану, стадії його розвитку, а також едафічні умови, обумовлені стратиграфією та потужністю штучних субстратів і багаторічним повеневим режимом річки Самари.

2. Спектру життєвих форм притамане домінування довгокореневищних полікарпічних трав. Багаторічне зростання ролі арідного елемента свідчить про формування структури, близької до зональної флори.

3. Аналіз флороценотипів показав провідну роль рудірантного комплексу, що пояснюється впливом антропогенних факторів (пожежи), після чого відбувається перша стадія відновлення - заселення бур'янами. Участь у формувані флори лучного, степового та псамофітного ценотипів вказує на різні типи лісорослинних умов, створених штучними грунтами.

4. Адаптація рослин до трофності субстрату та його зволоження, до світлового режиму, змін у співвідношенні різних груп зумовлена потужністю рекультиваційного шару, що регулює едафічний об'єм та використання верхніх шарів техноземів.

5. В насадженнях обліпихи крушиноподібної найкращі показники росту та розвитку були зареєстровані на варіанті з максимальним шаром супіску. Кількість видів на цьому варіанті була більшою, ніж на чорноземному. Отже, нами рекомендується для вирощування обліпихи потужність супіску від 80 до 140 см.

\section{Бібліографічні посилання}

1. Бельгард А. Л. Лесная растительность юго-востока УССР. Киев: Изд-во Киев. унта, $1950.264 \mathrm{c}$.

2. Бельгард А. Л. Степное лесоведение. Москва: Лесная промышленность, 1971. 336 с.

3. Грицан Ю. И. Деструкция и воссоздание экоклиматопа нарушеных земель Западного Донбасса. Биологическая рекультивация нарушенных земель: материаль Международного совещания, (Екатеринбург, 3-7 июня 2002 г.). Екатеринбург: УрО РАН, 2003. C. $79-82$.

4. Лаптєв $\boldsymbol{O}$. $\boldsymbol{O}$. Екологічна оптимізація біогеоценотичного покриву в сучасному урболандшафті. Київ: Держкомет України по житлово-комунальному господарству. 1998. 206 с.

5. Масюк $\boldsymbol{A}$. $\boldsymbol{H}$. Вертикальная структура насаждений облепихи крушиновидной на рекультивированных землях. Питання степового лісознавства та лісової рекультивачії земель. Дніпропетровськ: РВВ ДНУ, 2003. С. 39-52.

6. Масюк A. Н. Влияние мощности отсыпки рекультивированного эдафотопа на структуру и продуктивность древостоя облепихи крушиновидной в условиях степи Украины. Биологическая рекультивация и мониторинг нарушенных земель: материальы Междунар. науч. конф. Екатеринбург, 2007. С. 464-477. 
7. Масюк A. Н. Особенности формирования корневой системы робинии лжеакации в разных лесорастительных условиях, созданных на рекультивированных землях. Грунтознавство. 2009. Т. 10, № 1-2. С. 65-70.

8. Масюк $\boldsymbol{A}$. $\boldsymbol{H}$. Структурно-функциональная организация насаждений облепихи крушиновидной. Антропогенные воздействия на лесные экосистемы степной зоны. Днепропетровск, 1990. С. 101-112.

9. Определитель высших растений Украины / отв. ред. Ю. Н. Прокудин. Киев: Наук. думка, 1987. 548 с.

10. Программа и методика биогеоценотических исследований / под. ред. Н. В. Дылиca. M., 1974. 402 c.

11. Tарасов B. B. Флора Дніпропетровської та Запорізької областей. Дніпропетровськ: Вид-во ДНУ та Ліра, 2005. 276 с.

12. Экология города. Под ред. Ф. В. Стольберга. Киев: Либра, 2000. 464 с.

13. Ярошенко П. Д. Геоботаника. Основные понятия, направления и методы. Москва; Ленинград: Изд-во АН СССР, 1961. 474 с.

Надійшла до редколегії 25.08.2017 p.

УдК $58.087+581.1$

I. О. Зайцева

Дніпровський національний університет імені Олеся Гончара

\section{КІЛЬКІСНА ОЦІНКА ПОСУХОСТІЙКОСТІ ІНТРОДУЦЕНТІВ РОДУ SYRINGA L. В УМОВАХ СТЕПОВОГО ПРИДНІПРОВ'Я}

Проведено комплексне дослідження показників, що характеризують стійкість інтродукованих видів роду Syringa L. до дії стресових гідротермічних факторів. Швидкість водовіддачі тканинами листя, розрахована з використанням регресійного аналізу, може служити діагностичним критерієм реакції рослин на посуху. Кількісні оцінки водоутримуючої здатності корелюють із оцінками польової посухостійкості в період вегетації і визначаються вмістом розчинних фракцій білків протопласту клітин.

Ключові слова: водний режим, посухостійкість, види бузку, регресійний аналіз, вміст білків, водоутримуюча здатність листя.

\section{И. А. Зайцева \\ Днепровский национальный университет имени Олеся Гончара \\ КОЛИЧЕСТВЕННАЯ ОЦЕНКА ЗАСУХОУСТОЙЧИВОСТИ ИНТРОДУЦЕНТОВ РОДА SYRINGA L. В УСЛОВИЯХ СТЕПНОГО ПРИДНЕПРОВЬЯ}

Проведено комплексное исследование показателей, характеризующих устойчивость интродуцированных видов рода Syringa L. к действию стрессовых гидротермических факторов. Скорость водоотдачи тканями листа, рассчитанная с использованием регрессионного анализа, может служить диагностическим критерием реакции растений на засуху. Количественные оценки водоудерживающей способности коррелируют с оценками полевой засухоустойчивости в период вегетации и определяются содержанием растворимых фракций белков протопласта клеток.

Ключевые слова: водный режим, засухоустойчивость, виды сирени, регрессионный анализ, содержание белков, водоудерживающая способность листьев.

(C) I. О. Зайцева, 2017 